\title{
Regulatory $T$ cells in dogs with multicentric lymphoma: peripheral blood quantification at diagnosis and after initial stage chemotherapy
}

\author{
[Células T reguladoras em cães com linfoma multicêntrico: quantificação, em sangue periférico, \\ no momento do diagnóstico e após etapa inicial do tratamento quimioterápico] \\ T.D. Munhoz ${ }^{1}$, L.A. Anai ${ }^{2}$, D.M. Fonseca ${ }^{3}$, L.M. Semolin ${ }^{2}$, F.R. Sueiro ${ }^{4}$, M. Tinucci-Costa ${ }^{2}$ \\ ${ }^{1}$ Centro Universitário Barão de Mauá - Ribeirão Preto, SP \\ ${ }^{2}$ Universidade Estadual Paulista- Jaboticabal, SP \\ ${ }^{3}$ Universidade de São Paulo- Ribeirão Preto, SP \\ ${ }^{4}$ VetPat - Campinas, SP
}

\begin{abstract}
Lymphoma is the most common hematopoietic malignancy in dogs and one of the most frequent among all neoplastic diseases in this species. It can occur in several anatomical locations with distinct histological and immunophenotypes. Depending on the host immune response towards the tumor, prognosis information could be collected. Because its well established immunosuppressant, antitumor activity, the function of regulatory $\mathrm{T}$ cells (Tregs) in canine neoplasias has been investigated. In this study, we sought to quantify, using flow cytometry, the Tregs subpopulation in peripheral blood of healthy dogs (10) and in those diagnosed with type-B (14) and type-T (8) multicentric lymphoma before (at diagnosis) and after the first cycle (5-week) of 19-week Madison-Wisconsin (MW) protocol of chemotherapy. Our results indicated that dogs with lymphoma showed higher percentage of Tregs $(18,84 \pm 2,56)$ when compared to healthy dogs $(4,70 \pm 0,50)(\mathrm{P}<0,01)$. In addition, 5-week chemotherapy treatment reduced the Tregs subpopulation $(7,54 \pm 1,08)$ to levels similar to control $(4,70 \pm 0,50)(\mathrm{P}>0,05)$. There was no difference in Tregs percentage between B-type $(17,45 \pm 2,77)$ and T-type $(21,27 \pm 5,27)$ lymphoma $(\mathrm{P}>0,05)$. With this, we conclude that canine lymphoma increases Tregs in the peripheral blood and the MW protocol of chemotherapy reduces this cell subpopulation to control values.
\end{abstract}

Keywords: dogs, multicentric lymphoma, flow cytometry, regulatory T cells

\section{RESUMO}

O linfoma é a neoplasia hematopoiética mais comum nos cães e uma das mais frequentes, dentre todas as neoplasias, nesta espécie. Apresenta-se em diversas localizações anatômicas e pode apresentar classificações histológicas e imunofenotipos distintos. Dependendo da resposta imune do paciente frente à instalação de um tumor, algumas informações sobre o prognóstico podem ser obtidas. Atualmente, as células T reguladoras (Tregs) vêm sendo estudadas em algumas neoplasias caninas, por seu comprovado potencial imunossupressor, principalmente por inibir a resposta antitumoral. Neste contexto, o presente trabalho teve como objetivos quantificar, por citometria de fluxo, as células Tregs em sangue periférico de cães com linfoma multicêntrico de imunofenótipos B e T, respectivamente 14 e 8 cães, no momento do diagnóstico e após o primeiro ciclo de quimioterapia antineoplásica com o protocolo Madison-Wisconsin $(M W)$ de 19 semanas adaptado, e comparar com cães saudáveis $(n=10)$, buscando quantificá-las em cães com linfoma de diferentes imunofenótipos antes e após a $5^{a}$ semana do protocolo MW. Os resultados mostraram que cães com linfoma apresentaram uma porcentagem significativamente maior de Tregs $(18,84 \pm 2,56)$ quando comparada aos cães sem neoplasia $(4,70 \pm 0,50)(P<0,01)$. Além disso, após a quinta semana de tratamento houve uma significante redução da população de Tregs $(7,54 \pm 1,08)$,

Recebido em 2 de março de 2015

Aceito em 27 de julho de 2015

E-mail: thiago.munhoz@baraodemaua.br 
atingindo valores semelhantes a dos cães controle $(4,70 \pm 0,50)(P>0,05)$. Não houve diferença nas Tregs em relação aos imunofenotipos $B(17,45 \pm 2,77)$ e $T(21,27 \pm 5,27)(P>0,05)$. Concluiu-se que o linfoma em cães leva a um aumento de células Tregs e que o tratamento com o protocolo quimioterápico $M W$ reduz significativamente as células Tregs em sangue periférico, atingindo valores próximos aos dos cães saudáveis.

Palavras-chave: cães, linfoma multicêntrico, citometria de fluxo, células T reguladoras

\section{INTRODUCTION}

The immune system is capable of recognizing antigens associated with tumours and directing an effective cytotoxic response; however, this response often fails to inhibit local growth and the dissemination of neoplastic cells. Although a subpopulation of suppressor T-cells was discovered in the 70s, the lack of molecular and cellular techniques that could prove its existence meant that the population of $\mathrm{CD} 4{ }^{+} \mathrm{CD} 25^{+} \mathrm{T}$-cells with potent supressing activity, denominated regulatory T-cells, was only described in 1995 (Sakaguchi et al., 1995).

Intensive research has been done on regulatory T-cells (Treg) function in the physiological immune response and their role in various infectious, allergic, neoplastic and autoimmune diseases and transplant immunology (Cools et al., 2007). Other markers expressed by the Treg cells have also been detected, such as the CTLA4 (cytotoxic $T$ lymphocyte antigen 4), GITR (glucocorticoid-induced TNF-receptor-related protein), CD103, CD45RO, CD73 and CD39, amongst others (Akbar et al. 2007; Deaglio et al. 2007).

Foxp3 factor transcription takes place predominantly in thymic and peripheral Treg cells. Naïve T-cells transfected with Foxp3 mRNA developed regulating cellular characteristics and became anergic and suppressive in vitro. Furthermore, the phenotype expression and the production of cytokines and other molecules by these cells were similar to those by Treg cells. Thus, the Foxp3 gene is considered of great importance in the development and function of these cells (Sakaguchi 2005; Knueppel et al., 2011; Benoist and Mathis 2012).
The presence of Treg cells in some canine tumours (carcinomas, sarcomas, melanomas, osteosarcomas) has been investigated in recent years. Even though lymphoma is the main haematopoietic neoplasia and one of the most frequent tumours found in dogs, the reports available in the literature are scarce. A recent study (Mitchell et al., 2012) concluded that the predominance of Treg cells in dogs with lymphoma hinders the proliferation of antitumour effector T-cells, such as $\mathrm{CD} 4^{+}$and $\mathrm{CD} 8^{+}$, resulting in a worse prognosis for the patients.

Thus, the aim of this study was to quantify the Treg cells of dogs with immunophenotypes B and $\mathrm{T}$ multicentric lymphomas before and after chemotherapy and correlate the findings with the subpopulations of $\mathrm{CD}^{+}$and $\mathrm{CD}^{+} \quad \mathrm{T}$ lymphocytes in order to understand the role of Treg cells in canine lymphoma.

\section{MATERIAL AND METHODS}

The protocol for this experiment was reviewed and approved by the Ethics Committee on Animal Use (CEUA), Univ Estadual Paulista/Jaboticabal under number 027665/10.

The lymphoma group (LG) consisted of 22 male and female dogs $(7,2 \pm 1,7$ years $)$ diagnosed with multicentric lymphoma by cytology of the affected lymph node (in most cases, the popliteal) and confirmed by histopathology (performed after the excisional lymph node biopsy), according to the World Health Organisation (WHO) guidelines (SUEIRO et al., 2004), after being admitted to the Oncology Clinic of the Veterinary Hospital of FCAV/UNESP - Univ Estadual Paulista, Jaboticabal-SP, Brazil. The control group (CG) consisted of 10 healthy male and female dogs $(6,5 \pm 2,9$ years). Physical examination and 
complementary laboratory tests were performed to ensure the health status of the animals from CG (at the start of the experiment) and from LG at the time of diagnosis, weekly before chemotherapy sessions and at the end of the $5^{\text {th }}$ week, which marked the end of the experiment. Dog owners consent was obtained for all animals taking place in this study.

Immunohistochemistry was performed using the horseradish peroxidase (HRP) and 3,3' diaminobenzidine tetrachloride (DAB) method. Slides were incubated with the primary antibody at the standardized dilution (anti-CD3 - clone F.7.2.38 dilution 1:100; anti-CD79 $\alpha$ - clone HM57 dilution 1:20; both Dako $^{\circledR}$ ) overnight $(18 \mathrm{~h})$, at $4^{\circ} \mathrm{C}$, and washed is TRIS buffered solution (Tris- $\mathrm{HCl}-0.05 \mathrm{M}, \mathrm{NaCl}-0.15 \mathrm{M}$; $\mathrm{pH}=7.6$ ). Subsequently, slides were incubated with Envision polymer (Dako, Carpinteria, CA, USA) and washed thrice in TRIS buffered solution. Colour development was obtained through the use of DAB (DakoCytomation, Carpinteria, USA) and slides were counterstained with Harrys Haematoxylin. After dehydration through increasing concentrations of alcohol, slides were placed in xylene and mounted with resin and cover slip.

Before the start of chemotherapy, animals with lymphoma underwent clinical evaluation and tumour staging was determined according to the WHO guidelines. Blood samples $(10 \mathrm{~mL})$ were obtained by jugular venepuncture and kept in heparinized vacuum tubes for leucocyte separation for flow cytometry.

Dogs were subjected to the adapted 19-week Madison-Wisconsin chemotherapy protocol (UW-19) (Hosoya et al., 2007; Chun et al., 2009). Leucocyte separation for flow cytometry was only repeated in the LG after the $5^{\text {th }}$ week of treatment.

Mononuclear cells were isolated from $10 \mathrm{~mL}$ of blood collected in heparinised tubes. The blood samples were diluted (v:v) in sterile PBS $(\mathrm{NaCl}$ $137 \mathrm{mM}, \mathrm{KCl}-2.7 \mathrm{mM}, \mathrm{Na}_{2} \mathrm{HPO}_{4}-8.1 \mathrm{mM}$ and $\left.\mathrm{KH}_{2} \mathrm{PO}_{4}-1.5 \mathrm{mM} ; \mathrm{pH}=7.2\right)$ and separated by Ficoll-Paque PLUS gradient $\left(\mathrm{GE}^{\circledR}\right)$. After centrifugation at $1500 \mathrm{rpm}$ for 30 minutes, the mononuclear cell ring was collected, resuspended in PBS and centrifuged at $1500 \mathrm{rpm}$ for 10 minutes. The supernatant was discarded and the leucocyte ring resuspended in $2 \mathrm{~mL} \mathrm{ACK}$ erythrocyte lysing buffer $\left(\mathrm{NH}_{4} \mathrm{Cl}-0.15 \mathrm{mM}\right.$, $\mathrm{KHCO}_{3}-10 \mathrm{mM}$, EDTA - 0.1mM; $\mathrm{pH}=7.3$ ) for 5 minutes before being once again centrifuged. The cells were washed and resuspended in $1 \mathrm{~mL}$ PBS and subsequently counted using a Neubauer chamber. Each tube received $5 \mu \mathrm{L}$ of autologous serum and incubated for $40 \mathrm{~min}$ to block unspecific reactions before being incubated with superficial and intracellular antibodies for 30 minutes.

The suspended mononuclear cells were identified and quantified according to their size, granulation and fluorescence intensity by a flow cytometer using antigens for PanT $\left(\mathrm{BD}^{\circledR}\right.$, clone LSM 8.358, $1 \mu \mathrm{L}), \mathrm{CD}^{+}{ }^{\left(\text {Serotec }^{\circledR}\right.}{ }$, clone YKIX $302.9,1 \mu \mathrm{L}$ ) and $\mathrm{CD}^{+}$cells $\left(\right.$Serotec $^{\circledR}$, clone YCATE 55.9, $1 \mu \mathrm{L})$ and intracellular Foxp $3^{+}$ (eBioscience ${ }^{\circledR}$, clone FJK-16s, $2 \mu \mathrm{L}$ ). Cells were washed and received $100 \mu \mathrm{L}$ PBS-formalin solution. A total of $1 \times 10^{6}$ cells were used for cell-surface marking and $2 \times 10^{6}$ cells for intracellular marking.

Six tubes were obtained per animal: Tube 1 non-marked cells; Tube 2 - cells marked with control isotypes; Tube 3 - cells marked with CD4 FITC, CD8 PE and PanT APC antibodies; Tube 4 -non-marked cells; Tube 5 - cells marked with control isotypes; Tube 6 - cells marked with CD4 FITC, PanT APC and Foxp3 PE antibodies. The cells from Tubes 4, 5 and 6 were subjected to membrane permeabilization with permeabilization/fixation and permeabilization solutions (eBioscience ${ }^{\circledR}$ cat 00-5223 and cat 00-8333, respectively).

Cytoflourimetric analysis was performed within 24 hours of blood sampling. Cellular preparation was obtained using FACSCanto II. At least fifty thousand events on the lymphocyte gate were collected per tube and analysed using the FlowJo programme. Mouse anti-IgG2a antibody was used as the control isotype antibody for each fluorochrome.

T test was used to compare two variables, when normally distributed. However, when these 
variables were not normally distributed the Mann Whitney test was used for analysis. The ANOVA F-test was used to compare 3 variables, when normally distributed and the Tukey test to compare paired means. Variables that were not normally distributed were analysed by nonparametric ANOVA (Kruskal-Wallis) and the paired comparison by the Dunn test. Significance was considered at 5\%. GraphPad Prism 5 (GraphPad Prim5 software package, GraphPad Software, San Diego, CA, USA) was the statistical program of choice for the analysis.

\section{RESULTS}

Dogs with lymphoma showed significantly $(\mathrm{P}<0.01)$ higher percentages of Treg cells $(18.84 \pm 2.56)$ than healthy dogs $(4.70 \pm 0.50)$. However, when $\mathrm{CD}^{+}$and $\mathrm{CD} 8^{+}$subpopulations were analysed and compared between the control group $(56.23 \pm 2.53 ; 26.33 \pm 2.63$, respectively) and the lymphoma group (48.22 \pm 3.06 ; $25.27 \pm 2.96$, respectively), the percentages of $\mathrm{CD}^{+}$and $\mathrm{CD}^{+}$cells did not vary significantly $(\mathrm{P}=0.1$ and $\mathrm{P}=0.8$, respectively) between the groups. The mean value for the groups and the standard error of the means are detailed in Fig. 1. A diagram illustrating the choice of gates can be seen in Figure 2.
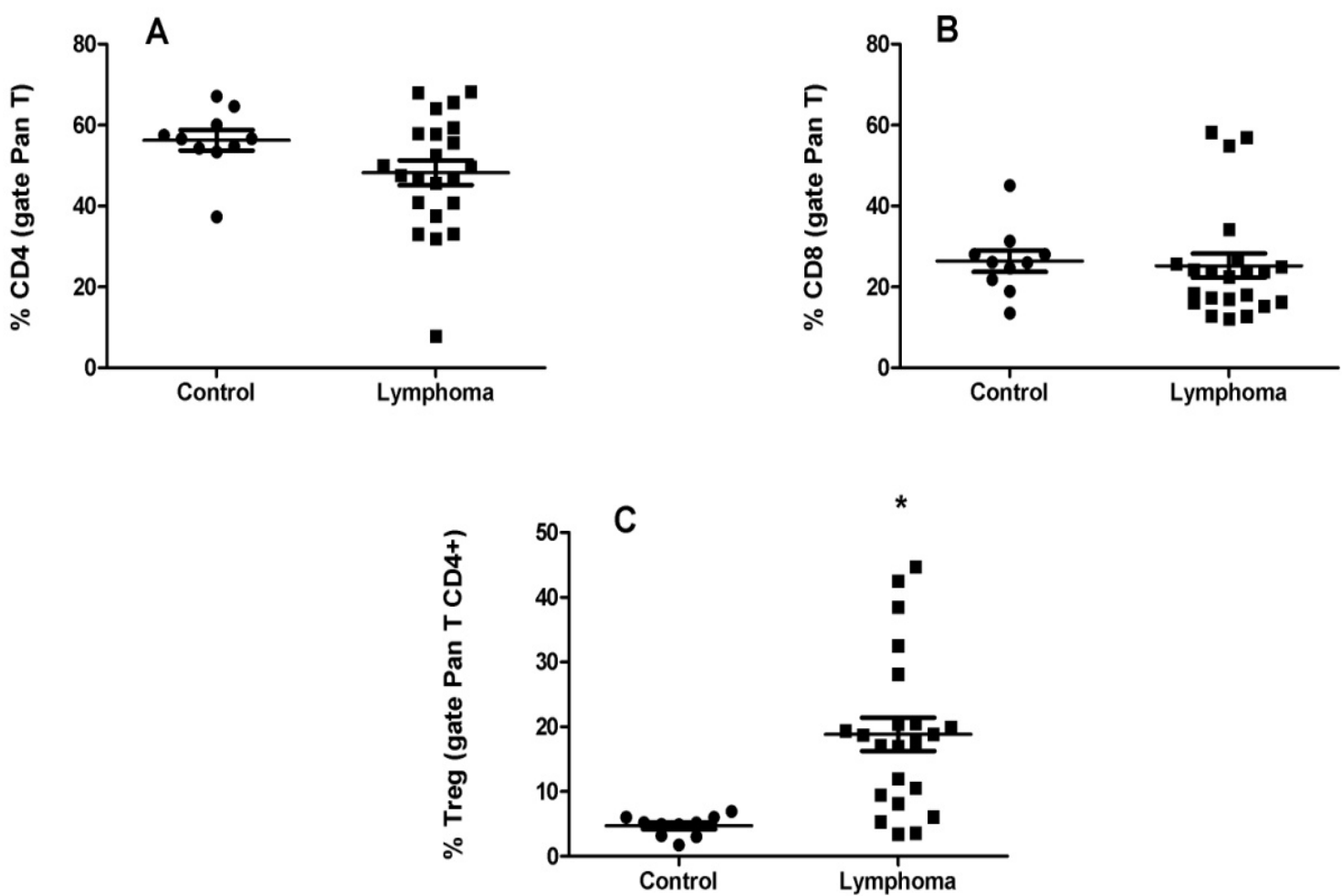

Figure 1. Evaluation of subpopulations of CD4 + (A), CD8 + (B) lymphocytes and regulatory T cells (Treg) (C) in peripheral blood of healthy dogs (control) and dogs with lymphoma. Results are presented as mean \pm standard error of the mean percentage (\%). 

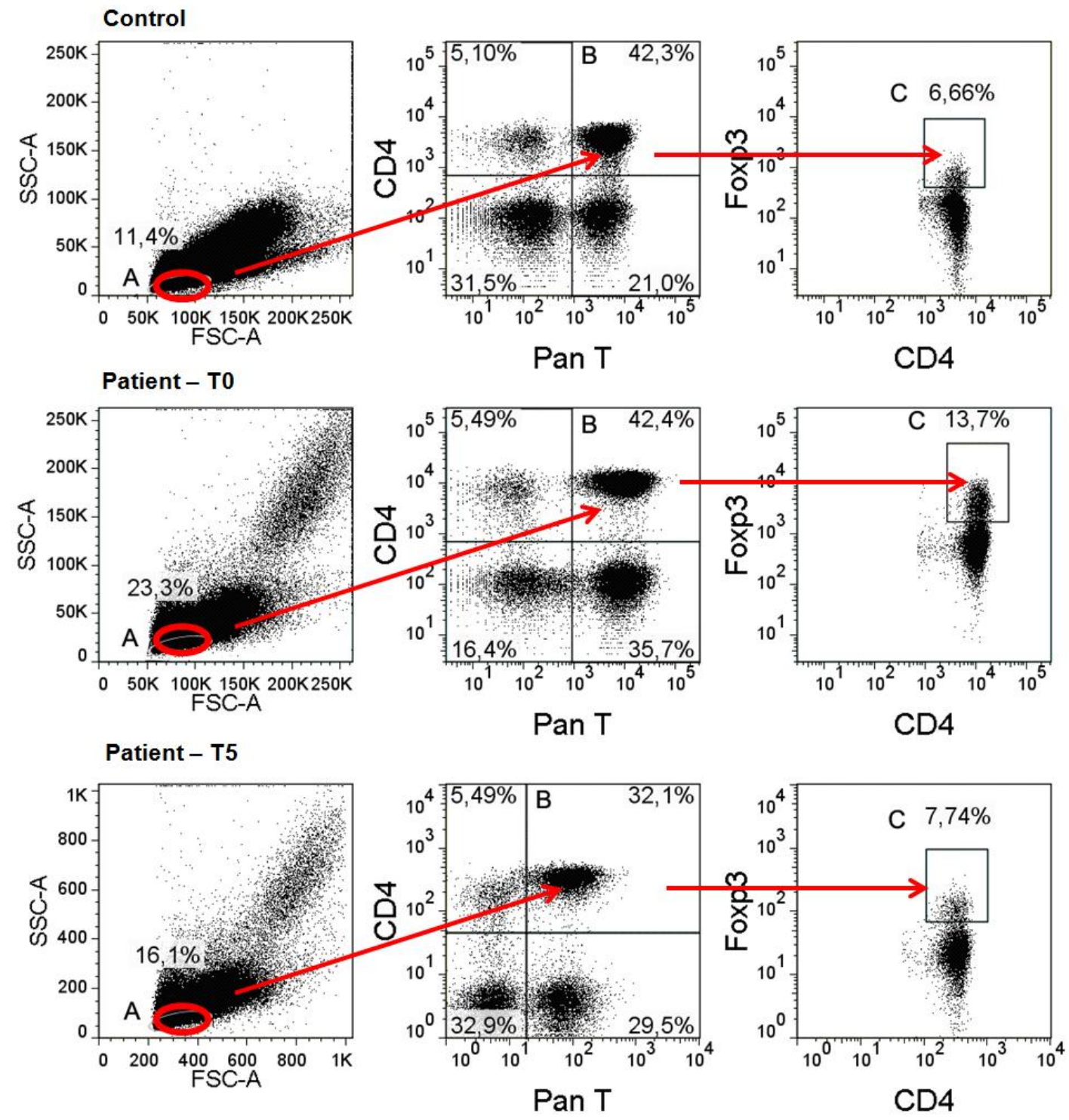

Figure 2. Representative flow chart of lymphocyte gates (A); from it the gate of CD4 + lymphocytes (B) and, from this, the gate of CD4 + Foxp3 + (Treg) (C) of a dog control (upper panel) and a dog with lymphoma in M0 (patient - T0, middle panel) and M5 (patient - T5, lower panel).

When the percentage of $\mathrm{CD}^{+}$and $\mathrm{CD}^{+}$subpopulations were compared before $(48.22 \pm 3.06 ; \quad 25.27 \pm 2.96$, respectively) and after $(53.75 \pm 3.01 ; 26.65 \pm 2.75, \quad$ respectively) chemotherapy, no significant $(\mathrm{p}=0.06$ and $\mathrm{p}=0.95$, respectively) difference could be observed. On the other hand, there was a significant reduction $(\mathrm{P}<0.01)$ in the percentage of Treg cells post-chemotherapy (7.54 \pm 1.08$)$ when compared to the time of diagnosis (18.84 \pm
2.56), as illustrated in Figure 3. The level of Treg cells in LG animals after chemotherapy (M5) was similar to that of those in the $\mathrm{CG}(\mathrm{P}>0.05)$.

No significant $(\mathrm{p}=0.48)$ difference was observed between the percentage of Treg cells in type B

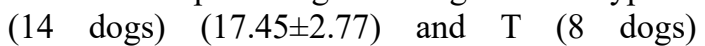
(21.27 \pm 5.27$)$ lymphomas, even though type $\mathrm{T}$ showed higher levels of Treg cells than type B lymphomas, as illustrated in Figure 4. 

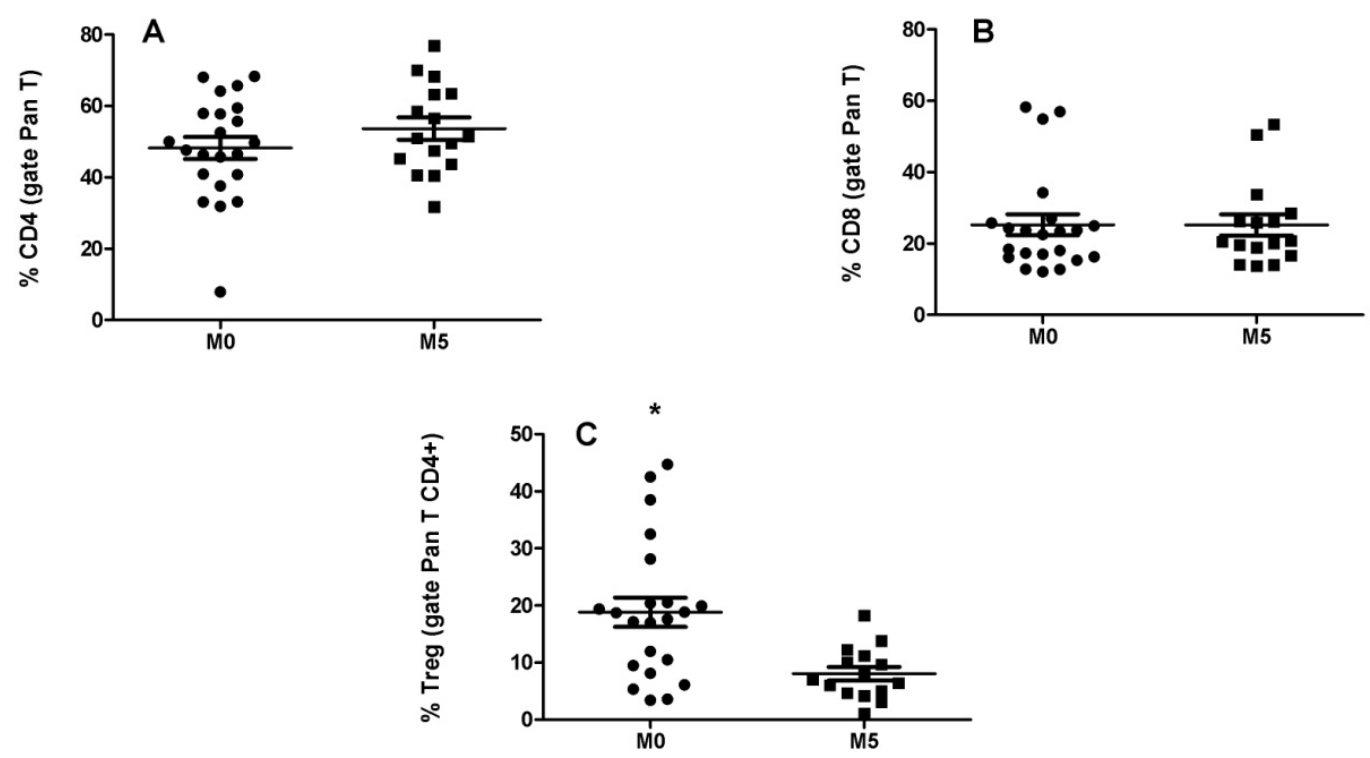

Figure 3. Evaluation of subpopulations of CD4 + (A), CD8 + (B) lymphocytes and regulatory $\mathrm{T}$ cel (Treg) (C) in peripheral blood of dogs with lymphoma before ( T0) and after (M5) to chemotherapy. Results are presented as mean \pm standard error of the mean percentage $(\%)$.

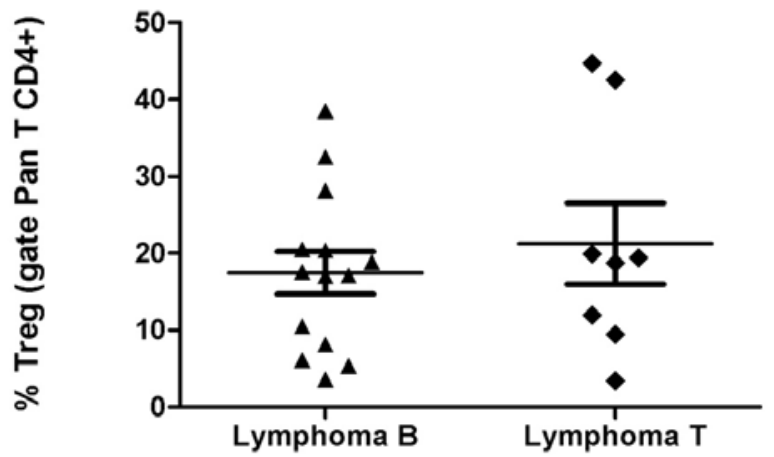

Figure 4. Evaluation of population of regulatory $\mathrm{T}$ cells (Treg) in peripheral blood of dogs with lymphoma type $\mathrm{B}$ and lymphoma type $\mathrm{T}$. These results are presented as mean \pm standard error of mean in percentage $(\%)$.

\section{DISCUSSION}

Although, in this study, no significant difference was observed in the subpopulations of $\mathrm{CD}^{+}$and $\mathrm{CD}^{+} \mathrm{T}$-cells in dogs with lymphoma, these animals showed higher levels of $\mathrm{CD}^{+}$and $\mathrm{CD}^{+}$cells than those of the control group. Similar results have been previously reported by O'Neill et al. (2009), who analysed dogs with various types of neoplasia (sarcoma, carcinoma, lymphoma and mastocytoma) and by Mitchell et al. (2012) in dogs with type B lymphoma. On the other hand, other studies (Winnicka et al., 2002; Walter et al., 2006) have reported significant differences between healthy and neoplastic dogs and have attributed such differences to factors related to the tumours, suggesting that these tumours can be suppressive; however, no information on the type of suppression was provided (Winnicka et al., 2002).

Some factors could have influenced this analysis and may explain some of the discrepancies in the results. Firstly, the way of expressing the results 
could be one of these factors since the relative values of $\mathrm{CD}^{+}$and $\mathrm{CD} 8^{+}$were transformed into absolute values (in relation to the number of lymphocytes obtained in the haemogram) (Winnicka et al., 2002). Another factor would be to analyse together data from different types of tumours, as described by O'Neill et al. (2009). Lastly, patients with one type of tumour with various histological classifications and immunophenotypes, such as lymphoma, could be analysed the same way by the same analysis.

As a matter of fact, Winnicka et al. (2002) did not specify the immunophenotype of the lymphoma studied and Mitchell et al. (2012) only included in their analysis immunophenotypes B. Therefore, the variations observed could be individual variations or related to the type of tumour being studied. With these limitations in mind, the present study has only considered dogs with immunophenotypes B and $\mathrm{T}$ lymphomas, thus allowing comparison between the groups and ensuring greater homogeneity of the results.

It was observed that the population of Treg cells was 4 times greater in the lymphoma group than in the control. These results are in agreement with those of other studies in canine tumours (Biller et al. 2007; Horiuchi et al. 2009; O'Neill et al. 2009; Mitchell et al. 2012), confirming that this subpopulation of lymphocytes is increased in cases of neoplasia.

There is compelling evidence that the tumour microenvironment determines local expression of cytokines and the activity of the cells present. The complex interdependency between the tumour cells, the tumour stroma and the infiltrated haematopoietic cells determines the kind of local immune response, which is in part induced by the secretion pattern of local inflammation regulating cytokines and chemokines (Trinchieri, 2011). Infiltrated activated macrophages and lymphocytes from the microcirculation are the greatest sources of pro-inflammation cytokines, growth factors and angiogenic factors. The extensive infiltration of leucocytes in solid tumours is controlled, in part, by the local production of chemokines by tumour cells. These chemokines in conjunction with the cytokines and growth factors influence the survival of tumour cells and neo-angiogenesis
(Schottenfeld and Beebe-Dimmer, 2006). It is known that chemokines stimulate Treg cell migration to the tumour microenvironment and other factors, such as immunosuppressive cytokines (TGF- $\beta$, IL-6), promote the expansion and conversion of conventional T-cells into Treg cells (Zou, 2006).

$\mathrm{CD}^{+}$T-cells orchestrate adaptive immune responses based on cytokine secretion pattern. According to the invading antigen (bacteria, fungi, tumour cells, amongst others) IFN- $\gamma$ and IL-12 direct the response to type 1 helper (Th) Tcells; IL-4 to Th2 and TGF- $\beta$ and IL-6 to Th17. Even though Treg cells are heterogeneous in their functions, immunosuppressive cytokines (TGF- $\beta$, IL-6) can determine their suppressive function (Li and Boussiotis 2011). Many aspects of Treg cell function are still under investigation and the data available is often derived from human or laboratory animal studies. The lack of studies in dogs with immunosuppressive diseases that involve cytokines and chemokines, such as lymphoma, emphasizes the need for further research.

In the current literature, few studies question the cause of the raised Treg cell population in dogs with neoplasia. Canine lymphocytic studies have shown that Foxp3 mRNA expression increases in activated lymphocytes cultured with IL-2 and TGF- $\beta$. These results were supported by simultaneous increases in IL-10 and TGF- $\beta$ mRNA expression in activated Treg cells (Biller et al. 2007).

The expression of TGF- $\beta$, cyclo-oxigenase- 2 (COX2) and of E2 prostaglandin by canine melanomas lead to the migration and proliferation of $\mathrm{CD}^{+}{ }^{+} \mathrm{Foxp}^{+}$cells and in situ conversion of CD4+ cells into Treg cells, and could thus be a possible explanation for the increase in Treg cell population observed in this tumour. Furthermore, the role of CCL22 in canine tumours (Tominaga et al., 2010) should be investigated in order to better understand the dynamics of Treg cells in dogs.

The role of Treg cells in human and canine tumours has already been determined. Treg cells cause immunosuppression through the production of IL-10 and TGF- $\beta$ cytokines (Curiel 2007) and attenuate $\mathrm{CD}^{+}$and $\mathrm{CD} 8^{+}$lymphocyte $\mathrm{T}$ function (Yang et al., 2006a; Yang et al. 
2006b; Horiuchi et al., 2009; Mitchell et al., 2012), which may explain why the population of these cell types are often decreased in dogs with tumours.

O'Neill et al. (2009) observed that dogs with T lymphoma showed greater Treg:CD8 ratio than dogs with other types of neoplasias, including B lymphoma, which suggested that tumour immunophenotype could influence Treg cell population. This was not observed in the present study. These results suggest that lymphoma signalling could be the same for the manipulation and differentiation of Treg cells independently of its immunophenotype. It is important to point out that the number of experimental shares analysed by O'Neill et al. (2009) was small (7 dogs with lymphoma: 3 immunophenotype B, 2 immunophenotype $\mathrm{T}$ and 2 dogs with undetermined immunophenotype) and thus does not represent a significant sample. With the exception of the studies by O'Neill et al. (2009), no other study has investigated Treg cell population in canine lymphoma subtypes.

The results of the present study show that the percentages of the subpopulations of $\mathrm{CD}^{+}$and $\mathrm{CD} 8^{+} \mathrm{T}$-cells were not altered by chemotherapy and are in agreement with the results of other studies in dogs with lymphoma and multicentric lymphoma (Winnicka et al., 2002; Mitchell et al., 2012) and in dogs with osteosarcoma (Walter et al., 2006). Gauthier et al. (2005) observed that chemotherapy caused a significant reduction in the absolute value of the majority of lymphocyte subpopulations of dogs with lymphoma. In essence, $\mathrm{CD}^{+}, \mathrm{CD}^{+} 0^{+}$and $\mathrm{TCR} \alpha \beta^{+}$lymphocytes relative population remained numerically similar to those of control animals, suggesting that the cytoreduction caused by chemotherapy would spare T-cells to a greater extent than other lymphocytes, which would support the findings of the present study.

Walter et al. (2006) observed that $\mathrm{CD}^{+}$function in dogs with lymphoma and osteosarcoma remained unaltered after chemotherapy treatment, as the dogs were still able to produce an $\mathrm{IgG}$ response specific to the KLH antigen (keyhole limpet hemocyanin), which is a TCD4 ${ }^{+}$ lymphocyte dependent response.
Amongst the lymphocyte subpopulation analysed in this study, Treg cells were the only ones altered by chemotherapy. These results are in agreement with those of Mitchell et al. (2012), who also reported a significant decrease in this cell type after chemotherapy. However, the above authors only used doxorubicin in the treatment of lymphoma, differently from the present study, which used a combination of 4 drugs (vincristine, cyclophosphamide, doxorubicin and prednisolone). Nevertheless, the effect of chemotherapy seems to have been selective in only reducing Treg cell subpopulation. The restoration of $\mathrm{CD}^{+}$ lymphocyte function in animals treated with doxorubicin coincided with the significant reduction of circulating Treg cell numbers, suggesting that the attenuation of the immunosuppression mediated by the Treg cells enabled the restoration of cytotoxic T-cells (Mitchell et al., 2012). These results are in agreement with those found in the present study, in which $16(94 \%)$ out of the 17 dogs analysed on the $5^{\text {th }}$ week of treatment showed tumour mass reduction, with $6(35 \%)$ complete and 10 $(59 \%)$ partial reductions.

\section{CONCLUSIONS}

This study has demonstrated that canine lymphomas are associated with an increase in Treg cell population and that the MW chemotherapy protocol significantly reduces the number Treg cells in peripheral blood after the $5^{\text {th }}$ week of treatment to levels similar to those of the control group. Thus, these findings suggest that the inhibition of the regulating function of Treg cells in dogs with lymphoma could be a potent therapeutic strategy for this neoplasia.

\section{ACKNOWLEDGEMENTS}

The authors would like to thank the staff of Genomic Vaccines Lab of under responsibility of Dr. Célio Lopes Silva, University of São Paulo, for their excellent technical support during the laboratory work. This study was supported by Fundação de Amparo à Pesquisa do Estado de São Paulo (FAPESP) - 2010/11908-5. 


\section{REFERENCES}

AKBAR, A.N.; VUKMANOVIC-STEJIC, M.; TAAMS, L.S.; MACALLAN, D.C. The dynamic coevolution of memory and regulatory CD4+ $\mathrm{T}$ cells in the periphery. Nat. Rev. Immunol., n.7, p.231-237, 2007.

BENOIST, C.; MATHIS, D. Treg cells, life history, and diversity. Cold Spring Harb. Perspect. Biol., n.4, p.1-14, 2012.

BILLER, B.J.; ELMSLIE, R.E.; BURNETT, R.C. et al. Use of Foxp3 expression to identify regulatory $\mathrm{T}$ cells in healthy dogs and dogs with cancer. Vet. Immunol. Immunopathol., n.116, p.69-78, 2007.

CHUN, R. Lymphoma: which chemotherapy protocol and why? Top. Comp. Anim. Med., n.24, p.157-162, 2008.

COOLS, N.; PONSAERTS, P.; VAN TENDELOO, V.F.; BERNEMAN, Z.N. Regulatory $\mathrm{T}$ cells and human disease. Clin. Dev. Immunol., n.2007, p.1-11, 2007.

CURIEL, T.J. Regulatory $\mathrm{T}$ cells and treatment of cancer. Curr. Opin. Immunol., n.20, p.241-246, 2008.

DEAGLIO, S.; DWYER, K.M.; GAO, W. et al. Adenosine generation catalyzed by CD39 and CD73 expressed on regulatory $\mathrm{T}$ cells mediates immune suppression. J. Exp. Med., n.204, p.1257-1265, 2007.

GAUTHIER, M.J.; AUBERT, I; ABRAMS-OGG, A. et al. The immunophenotype of peripheral blood lymphocytes in clinically healthy dogs and dogs with lymphoma in remission. J. Vet. Intern. Med., v.19, p.193-199, 2005.

HORIUCHI, Y.; TOMINAGA, M.; ICHIKAWA, M. et al. Increase of regulatory $\mathrm{T}$ cells in the peripheral blood of dogs with metastatic tumors. Microbiol. Immunol., v.53, p.468-474, 2009.

HOSOYA, K.; KISSEBERTH, W.C.; LORD, L.K. et al. Comparison of COAP and UW-19 protocols for dogs with multicentric lymphoma. J. Vet. Intern. Med., v.21, p.1355-1363, 2007.

KNUEPPEL, A.; LANGE, S.; SEKORA, A. et al. Phenotypic and functional characterization of freshly isolated and expanded canine regulatory T cells. Exp. Anim., v.60, p.471-479, 2011

LI, L.; BOUSSIOTIS, V.A. Molecular and functional heterogeneity of $\mathrm{T}$ regulatory cells. Clin. Immunol., v.141, p.244-252, 2011.

MITCHELL, L.; DOW, S.W.; SLANSKY, J.E.; BILLER, B.J. Induction of remission results in spontaneous enhancement of anti-tumor cytotoxic T-lymphocyte activity in dogs with B cell lymphoma. Vet. Immunol. Immunopathol., n.145, p.597-603, 2012.
O'NEILL, K.; GUTH, A.; BILLER, B. et al. Changes in regulatory $\mathrm{T}$ cells in dogs with cancer and associations with tumor type. J. Vet. Intern. Med., v.23, p.875-881, 2009.

SAKAGUCHI, S.; SAKAGUCHI, N.; ASANO, M. et al. Immunologic self-tolerance maintained $\mathrm{T}$ cells expressing IL-2 receptor $\alpha$-chains (CD25) breakdown of a single mechanism of self-tolerance causes various autoimmune diseases. J. Immunol., n.155, p. 11511164, 1995.

SAKAGUCHI, S. Naturally arising Foxp3-expressing $\mathrm{CD} 25+\mathrm{CD} 4+$ regulatory $\mathrm{t}$ cells in immunological tolerance to self and non-self. Nat. Immunol., n.6, p.345-352, 2005.

SCHOTTENFELD, D; BEEBE-DIMMER, J. Chronic inflammation: a common and important factor in the pathogenesis of neoplasia. C. A. Cancer J. Clin., n.56, p.69-83, 2006

SUEIRO, F.A.R.; ALESSI, A.C.; VASSALLO, J. Canine lymphomas: a morphological and immunohistochemical study of 55 cases, with observations on p53 immunoexpression. J. Comp. Path., v.131, p.207-213, 2004.

TOMINAGA, M.; HORIUCHI, Y.; ICHIKAWA, M. et al. Flow cytometric analysis of peripheral blood and tumor-infiltrating regulatory $\mathrm{T}$ cells in dogs with oral malignant melanoma. J. Vet. Diagn. Invest., v.22, p.438-441, 2010.

TRINCHIERI G. Inflammation. In: Devita Jr VT; Lawrence T; Rosenberg SA (eds) Cancer: principles \& practice of oncology, 9th ed. USA: Lippincott Williams \& Wilkins, 2011. p.193-202.

WALTER, C.U.; BILLER, B.J.; LANA, S.E. et al. Effects of chemotherapy on immune responses in dogs with cancer. J. Vet. Intern. Med., v.20, p.342-347, 2006.

WINNICKA, A.; JAGIELSKI, D.; HOFFMANNJAGIELSKA, M.; LECHOWSKI, R. Cytometric evaluation of peripheral blood lymphocytes in dogs with lymphoma during chemotherapy. J. Vet. Med. A. Physiol. Pathol. Clin. Med., v.49, p.303-306, 2002.

YANG, Z.Z.; NOVAK, A.J.; ZIESMER, S.C. et al. Attenuation of CD8+ T cell function by CD4+CD25+ regulatory T cells in B-cell non-Hodgkin's lymphoma. Cancer Res., v.66, p.10145-10152, 2006a.

YANG, Z.Z.; NOVAK, A.J.; STENSON, M.J. et al. Intratumoral $\mathrm{CD} 4+\mathrm{CD} 25+$ regulatory $\mathrm{T}$-cell-mediate suppression of infiltrating CD4+ T cells in B-cell nonHodgkin lymphoma. Blood, v.107, p. 3639-3646, $2006 \mathrm{~b}$.

ZOU, W. Regulatory T cells, tumour immunity and immunotherapy. Nat. Rev. Immunol., v.6, p.295-307, 2006. 